\title{
ATTACHMENT IN THE TEACHER-STUDENT DYAD AND GENDER ROLES
}

\author{
Maja Matrić \\ Faculty of Education, University of Maribor, Slovenia \\ maja.matric@gmail.com
}

Professional Paper

doi:10.5937/jouproman7-19503

\begin{abstract}
Attachment theory offers an exceptional insight into the individual's personality, since it can be used to explain his or her behaviour and cognitive patterns present in everyday interactions with people in domestic, educational or professional spheres. An overview of the literature helps us study early childhood attachment relationships, which consequently influence relationships formed later in life - here, the focus is on elementary education period, where attachment is used to look into the student-teacher relationship. Taking into account gender when exploring attachment relationships in the early childhood, as well as traditional notions of gender roles, we raise the question whether these are indeed elements defining the quality of a child's attachment relationship to a female or male teacher and propose a research plan.
\end{abstract}

Key words: attachment, childhood attachment, parent, teacher, gender

\section{Introduction}

We believe the quality of the relationship between the teacher and the student has a notable place in the learning process, as it is reflected in the students' and the teachers' well-being (Košir, 2013), and attachment is one aspect of this relationship. Attachment firstly forms in relation to the primary caregiver, and later on, to other important persons in the child's life (Cugmas, 1998a; Riley, 2011). In order to speak about the attachment between the child and the teacher, it is important to understand attachment patterns that form before the child enters school, as this is the period in which the child initially develops a relationship with the primary caregiver (usually the mother, but not necessarily) in the shape of positive or negative attachment which echoes the quality of the relationship between the caregiver and the child (Cugmas, 2003). By examining the relevant literature from the field of attachment, we try to establish the nature of early childhood attachment and its relation to attachment patterns a child forms in school. As we will explain, the child can develop negative or positive attachment relationships which can be noted doing the school years. We believe teachers have an important role in such cases, as they are often secondary attachment figures for many children and we try to determine the role of the quality of attachment between the teacher and the student. As the teaching profession is traditionally more feminised (Driessen, 2007), we also try to establish whether differences occur relating to the gender of the teacher. Here, we focus on the origins of traditional gender-roles and their place in the teaching environment. 


\section{Attachment theory}

Bowlby (1969) explained attachment as a relationship that usually forms between the child and the caregiver in the early years of the child's life, and continues to evolve during life. Bowlby says there is a universal tendency for attachment to form between the mother and the child - since the child is unable to take care of himself, a symbiosis has to emerge in relation to the mother or other primary caregiver. The author explains that attached children wish to be close to the attachment figure, particularly when they are frightened, tired or ill. Even though this is a biological relationship, differences can occur in the quality of attachment which reflects how well the caregiver detects and satisfies the child's needs (Cugmas, 1998a). Caregivers who answer the needs of the children fully and encourage their development, nurture emotions of love and self-worth within the children (Cugmas, 2003). On the other hand, poor care of children can result in negative perceptions of their selfcompetence and self-worth. As the child becomes attached to the caregiver, he or she internalizes the beliefs and the working model of the primary caregiver. Thus, daily activities in the presence of the primary caregiver co-shape the development of internal representations in children (Bretherton, 1992).

We are not able to measure the individuals' mental representations of attachment directly, but can do so indirectly by observing individuals' behaviour (Main, Kaplan, \& Cassidy, 1985). An instrument which allows us to do so is the strange situation procedure (Aisnworth \& Bell, 1970). The instrument is based on observing behavioural patterns between the mother and the child in an unknown experimental environment during separation times. By observing the child's reaction to the mother's return, we can determine the attachment relationship between the two. Ainsworth used this procedure to confirm the assumption that children have to develop secure attachment to the parents before they are ready to face strange situations. The author differs between three types of attachment: secure attachment, anxious-avoidant attachment and anxious-resistant attachment. Securely attached children will perceive the mother as a safe base and feel free to explore. Such children perceive themselves as loved and their attachment figure as trustworthy and helpful. Anxious-avoidant attachment was noticed with children whose mothers either avoided physical contact or being gentle (Ainsworth, Blehar, Waters, \& Wall, 1978), or demonstrated negative interactions (van IJzendoorn, Goldberg, Kroonenberg, \& Frenkel, 1992). In such cases, the children perceive themselves as unloved and are usually independent of the attachment figure (Liotti, 1992). Anxiousresistant attachment is evident when the child does not explore the surroundings and exhibits severe stress when separated from the mother. Such child feels threatened and does not trust the attachment figure (Liotti, 1992). Further research unveiled a fourth type of attachment, disorganized/disoriented (Main \& Solomon, 1986), where the child lacks appropriate coping mechanisms when faced with separation stress. Instead, the child expresses mixed responses to the separation, such as seeking the proximity of the mother, followed by avoidance the very next moment. 


\section{Attachment to primary caregivers}

Experiences with the attachment figure help shape the development of children's internal concepts and working models (Bretherton, 1992), provided the attachment figure manages to successfully satisfy the child's needs, as well as find balance between helping the child and still giving him or her the freedom to explore (Cugmas, 2001b). Accepting the child is another important variable in the development of secure attachment, which is evident when the caregivers are able to identify with the child's needs and do not reject the child as an obstacle when fulfilling their own needs (Cugmas, 2001b).

Research has shown the different roles of the mother and the father in the development of attachment relationships (Schneider Rosen \& Burke, 1999). Traditionally, the mothers tend to be the primary caregiver and thus have a more prominent role in attachment relationships, as is the case in western cultures (Lamb, 1981). In such cases, the role of the father is indirect; the father supports the mother. Van IJzendoorn and Wolff (1997) reveal a barely present relatedness between the quality of attachment to the mother and the father, which is supported by Schneider Rosen and Burke (1999). On the other hand, Steele, Steele and Fonagy (1996) reveal that the quality of attachment towards one parent positively predicts attachment to the other. Cugmas (2001b) explains that the father's sensibility is slightly less related to the quality of the child's attachment to the father, but adds that the sensibility of both parents depends on the same variables: wellbeing in the family, work, or traumatic situations, such as a divorce.

\section{Attachment in school}

Research shows that the children do not only form attachment relationships with the caregivers, but also other persons they are looked after by (Cugmas, 2001b). In these cases, different attachment relationships are complementary, as care from others can ameliorate poor attachment in the primary environment (Carlson, 1995). Goossens and van IJzendoorn (1990) report that children who develop anxious types of attachment to the parents, develop safe attachment to professional caregivers. Cugmas (2009a) supports this notion by placing professional caregivers in the group of primary caregivers, alongside the mother and the father. In her research, the author discovered correlations between the concrete behaviour of the professional caregiver and the quality of attachment between the child and the professional caregiver. The author continues to explain that the development of trust, communicational skills and attachment in children happen in safe and healthy environments, characterized by appropriate interactions with adults. In school, these adults are teachers and we should not neglect the importance of teacher-student relationships, which are reflected in the child's emotional and intellectual development and learning motivation (Connell \& Wellborn, 1991; Wentzel, 1999). Teacher support also helps develop the feeling of belongingness and positive student identity (Furrer \& Skinner, 2003; Connell \& Wellborn, 1991). 
If the primary caregivers are a safe base at home, from which the child feels free to explore the environment, similar can be said about teachers in the educational context, where the students rely that the teacher will be predictable (as safe base) and manage to challenge them appropriately (Riley, 2009). Riley (2011) explains that, unlike parents, the teachers encounter numerous children with different developmental histories and types of attachment. With this in mind, the teacher might be more understanding to the fact that some students are more or less difficult to deal with than others. Separation in the teacher-student dyad is a common occurrence due to the timetable, weekends or holidays. Securely attached students are able to comprehend that these separations are not permanent, while other forms of attachment may result in stress or fear when the student is separated from or united with the teacher (Riley, 2011). The author continues to explain that attachment patterns of the teacher should be taken into consideration as well, as they help form attachment in the teacher-student dyad, which is complex in nature. At first glance, one may say it is characterized by uneven distribution of power (the teacher leads, the student follows), however, both parties have their power within the dyad. The teacher can become the secure base the children use to correct negative attachment patterns. Namely, a child who does not manage to develop secure attachment at home, seeks positive emotional experiences in school, expresses a desire to remain in school or wishes to become just like the teachers (Riley, 2009). On the other hand, the teacher needs the care of at least one student in order to maintain their professional identity (without students, the teacher is not needed), or correct their own negative attachment patterns (Riley, 2011). Namely, teachers who have managed to develop secure attachment, are able to cope with separation from the student and can handle rejection better, while other types of attachment in teachers causes them to cope poorly with separation and rejection, resulting in aggressive behaviour on the part of the teacher.

\section{Gender roles and stereotypes - home vs. school}

Bem (1981) explains that children gather information on gender roles and insert them into their own cognitive scheme which goes on to control the behaviour of the child according to culturally accepted definitions of the female and the male. A child learns of typical behaviour of the man and the woman through observation of caregivers in the primary environment. Research (Arditti, Godwin, \& Scanzoni, 1991; Lamb, 1981) does not correlate gender identity of the parent with gender identity of the child, however, mother's gender identity seems to correlate positively with the development of female characteristics in a child, while gender identity of the father correlates with the development of typically male characteristics in a child. In the process of socialisation, the boys are encouraged to be more independent (Gurian, 1987), while girls are encouraged to be more dependant and indecisive (Rothblum, Solomon, \& Murakami, 1986). Such approaches can support the development of typically male (capable, rational, determined, assertive, and aggressive) and female (kind, nurturing, dependant, illogical, incompetent) stereotypes (Ashmore \& Del Boca, 1979; Avsec, 2002; Bem, 1981). 
We can notice that the teacher is a notable figure in the development of attachment relationships (Connell \& Wellborn, 1991; Furrer \& Skinner, 2003; Goossens \& van IJzendoorn, 1990; Riley, 2009; Riley, 2011; Wentzel, 1999), as well as the fact that gender roles and stereotypes of the female and the male come from the primary environment (Bem, 1981). This led us to consider whether gender of the teacher translates differently in attachment relationships in the teacher-student dyad. The feminisation of the teaching profession and concerns that stem from this have been present for a longer time (Driessen, 2007) which brings to question the students' perceptions of female and male teachers. Worries that the lack of male teachers may reflect negatively on the development of boys in school have been criticized by Skelton (2003), who finds the idea that female teachers can be good role models only for girls too stereotypical and an overgeneralization of gender roles. A research into stereotypes among male and female teachers reveals that those individuals who adhere to traditional gender roles, perceive the abilities of female teachers as lower (Dobbins, Cardy, \& Truxillo, 1986; Martell, 1996). This notion is further supported by Martell (1996) who explains that gender stereotypes lead to positive assessment of the abilities of men and negative assessment of the abilities of women.

\section{Conclusions}

Attachment formed in early childhood is an important aspect of development as it is reflected in the child's notions of the world (Cugmas, 2001b), attachment patterns in adulthood (Bretherton \& Munholland,
1999), and the individual's self-image (Cugmas, 2003). The development of internal working models does not stop in childhood, but changes and adapts in different situations throughout lifetime. Research shows that the gender of the primary caregivers shapes attachment relations differently (Schneider Rosen \& Burke, 1999), as the mother remains the primary attachment figure in most western cultures (Cugmas, 2001b; Lamb, 1981). Mother offers comfort and care, while the father supports the mother and encourages the child to explore the environment (Cugmas, 2001a). These processes are characterized by typical gender roles of the mother and the father that children observe in the primary environment (Avsec, 2002; Gurian, 1987). The child can develop different types of attachment to individual caregivers, however, secure attachment to both primary caregivers remains the optimal condition for the development of a competent and non-conflict inclined individual (Belsky, 1996; Lieberman, Doyle, \& Markiewicz, 1999).

Attachment in the teacher-student dyad is complementary to other attachment relationships (Cugmas, 2001b) and has the ability to correct or improve the existing attachment patterns (Goossens \& van IJzendoorn, 1990). This confirms the notable role of the teacher in a child's life. The quality of the relationship between the teacher and the student can influence the students' academic achievements (Pianta, Steinberg, \& Rollins, 1995), intellectual and emotional development, learning motivation and behavioural patterns (Connell \& Wellborn, 1991; Wentzel, 1999). Support from the teacher also fosters a sense of belonging to school and positive academic self-image (Connell \& Wellborn, 1991; Furrer \& Skinner, 2003). 
Gender stereotypes and traditional view of gender roles is present in professional environment (Dobbins, Cardy, \& Truxillo, 1986; Martell, 1996), but they such views internalized by those individuals, who actually perceive men and women in the sense of traditionally ascribed characteristics (Dobbins, Cardy, \& Truxillo, 1986). Therefore, if a child internalizes gender roles as typically male or typically female in the primary environment, he or she is likely to do so in the educational context as well. A research into teacher gender roles from the viewpoint of the student would reveal whether the students perceive female teachers as kind, caring, less strict and nondominant, and the male teacher as strict, determined and more competent. Establishing the role of the teacher's gender in teacher-student attachment could be investigated by means of hierarchical regression, where gender roles would be examined as predictors of the attachment relationship. We suggest the use of instruments which assess attachment, such as ECR - Experiences in Close Relationships (Fraley, Waller, \& Brennan, 2000), STRS - Student-teacher relatedness scale (Pianta, 2001) and establish gender roles, such as the BSRI - Bem Sex-role inventory (Bem, 1974). The results of the research would reveal whether concerns about the feminisation of the teaching profession and the development of boys in school is a concern that should be addressed, and how gender of the teacher predicts the quality of the attachment relationship in the teacher-student dyad; while including participants of different ages could help understand the aspect of cognitive development on children's perceptions of attachment and gender roles.

\section{Resources}

- Ainsworth, M. D. \& Bell, S. M. (1970), Attachment, exploration, and separation: Illustrated by the behavior of one-yearolds in a strange situation. Child Development, 41(1), 49-67. DOI: http://dx.doi.org/10.2307/1127388

- $\quad$ Ainsworth, M., Blehar, M., Waters, E., \& Wall, S. (1978). Patterns of attachment: A psychological study of the Strange Situation. Hillsdale, NJ: Erlbaum.

- Arditti, J. A., Goodwin, D. D., \& Scanzoni, J. (1991). Perceptions of parenting behavior and young women's gender role traits and preferences. Sex Roles, 25(3), 195-211. DOI: https://doi.org/10.1007/BF00289854

- $\quad$ Ashmore, R. D., \& del Boca, F. K. (1979). Sex stereotypes and implicit personality theory: Toward a cognitive-social psychological conceptualization. Sex Roles: A Journal of Research, 5(2), 219248. DOI: http://dx.doi.org/10.1007/BF00287932

- Avsec, A. (2002). Stereotipi o moških in ženskih osebnostnih lastnostih. Psihološka obzorja, 11(2), 23-35.

- Belsky, J. (1996). Parent, infant, and social-contextual antecedents of fatherson attachment security. Developmental Psychology, 32(5), 905-913. DOI: http://dx.doi.org/10.1037/00121649.32.5.905

- Bem, S. L. (1974). The measurement of psychological androgyny. Journal of Clinical and Consulting Psychology, 42(2), 155-162. DOI: http://dx.doi.org/10.1037/h0036215

- Bem, S. L. (1981). Gender schema theory: A cognitive account of sex typing. Psychological Review, 88(4), 354364. DOI: http://dx.doi.org/10.1037/0033295X.88.4.354

- Bowlby J. (1969). Attachment. Attachment and loss: Vol. 1. Loss. New York: Basic Books.

- $\quad$ Bretherton, I. (1992). Attachment and bonding. In V. B. Van Hasselt \& M. Hersen (Eds.), Perspectives in developmental psychology. Handbook of 
social development: A lifespan perspective (133-155). New York, NY, US: Plenum Press. DOI: http://dx.doi.org/10.1007/9781-4899-0694-6_6

- Bretherton, I., \& Munholland, K. A. (1999). Internal working models in attachment relationships: A construct revisited. In J. Cassidy \& P. R. Shaver (Eds.), Handbook of attachment: Theory, research, and clinical applications (89111). New York, NY, US: Guilford Press.

- Carlson, T. (1995). We hate gym: Student alienation from physical education. Journal of Teaching in Physical Education, 14(4), 467-477.

- Connell, J. P., \& Wellborn, J. G. (1991). Competence, autonomy, and relatedness: A motivational analysis of self-system processes. In M. R. Gunnar \& L. A. Sroufe (Eds.), The Minnesota symposia on child psychology, Vol. 23. Self processes and development (43-77). Hillsdale, NJ, US: Lawrence Erlbaum Associates, Inc.

- Cugmas, Z. (1998). Bodi z menoj, mami: razvoj otrokove navezanosti. Ljubljana: Center za psihodiagnostčna sredstva.

- Cugmas, Z. (2001a). Nova spoznanja o vlogi staršev pri razvoju otrokove navezanosti. Psihološka obzorja, 10(2), 51-66.

- Cugmas, Z. (2001b). Vloga očeta kot objekta otrokove navezanosti. Psihološka obzorja, 3(10), 89-104.

- Cugmas, Z. (2003). Narisal sem sonce zate. Ljubljana: Center za psihodiagnostična sredstva.

- Dobbins, G. H., Cardy, R. L., \& Truxillo, D. M. (1986). Effects of Ratee Sex and Purpose of Appraisal on the Accuracy of Performance Evaluations. Basic and Applied Social Psychology, 7(3), 225241. DOI: 10.1207/s15324834basp0703_5

- Driessen, G. (2007). The feminization of primary education: effects of teachers' sex on pupil achievement, attitudes and behaviour. Review of Education, 53(2), 183-203.

DOI: https://doi.org/10.1007/s11159-007-9039$\mathrm{y}$

- Fraley, R. C., Waller, N. G., \& Brennan, K. A. (2000). An item-response theory analysis of self-report measures of adult attachment. Journal of Personality and Social Psychology, 78(2), 350-365.

- $\quad$ Furrer, C., \& Skinner, E. (2003). Sense of relatedness as a factor in children's academic engagement and performance. Journal of Educational Psychology, 95(1), 148-162. DOI: http://dx.doi.org/10.1037/00220663.95.1.148

- Goossens, F. A., \& Van IJzendoorn, M. H. (1990). Quality of infants' attachments to professional caregivers: Relation to infantparent attachment and day-care characteristics. Child Development, 61(3), 832-837. DOI: http://dx.doi.org/10.2307/1130967

- Gurian, A. (1987). Depression and young girls: Early sorrow and depressive disorders. In R. Formanek \& A. Gurian (Eds.), Women and depression: A lifespan perspective (57-83). New York: Springer

- Košir, K. (2013). Socialni Odnosi v šoli. Maribor: Subkulturni azil, zavod za umetniško produkcijo in založništvo.

- $\quad$ Lamb, M. E. (1981). Father and child development: An integrative overview. In M. E. Lamb, (Ed.), The role of the father in child development. New York: John Wiley \& Sons.

- Lieberman, M., Doyle, A., \& Markiewicz, D. (1999). Developmental Patterns in Security of Attachment to Mother and Father in Late Childhood and Early Adolescence: Associations with Peer Relations. Child Development, 70(1), 202213.

DOI: $10.1111 / 1467-8624.00015$

- Liotti G. (1992). Disorganized/disoriented attachment in the ethology of the dissociative disorders. Dissociation, 5(4), 196-204.

- $\quad$ Main, M., \& Solomon, J. (1986). Discovery of an insecuredisorganized/disoriented attachment pattern. In T. B. Brazelton \& M. W. Yogman (Eds.), Affective development in infancy (95-124). Westport, CT, US: Ablex Publishing.

- Main, M., Kaplan, N., \& Cassidy, J. (1985). Security in infancy, childhood and adulthood: A move to the level of representation. In I. Bretherton \& E. 
Waters (Eds.), Growing points in attachment theory and research.

Monographs of the Society for Research in Child Development, 50(1-2, Serial No. 209, 66-104).

- Martell, R. F. (1996). What mediates gender bias in work behaviour ratings? Sex Roles, 35(3-4), 153-169. DOI: https://doi.org/10.1007/BF01433104

- Pianta, R. C. (2001). Student-Teacher Relationship Scale: Professional anual. Odessa, FL: Psychological Assessment Resources, Inc.

- Pianta, R. C., Steinberg, M. S., \& Rollins, K. B. (1995). The first two years of school: Teacher-child relationships and deflections in children's classroom adjustment. Development and Psychopathology, 7(2), 295-312. DOI: http://dx.doi.org/10.1017/S095457940000 6519

- Riley, P. (2009). An adult attachment perspective on the student-teacher relationship and classroom management difficulties. Teaching and teacher education, 25(5), 626-635. DOI: https://doi.org/10.1016/j.tate.2008.11.018

- Riley, P. (2011). Attachment theory and the teacher-student relationship - A practical guide for teachers, teacher educators and school leaders. London, New York: Routledge.

- $\quad$ Rothblum, E. D., Solomon, L. J., \& Murakami, J. (1986). Affective, cognitive, and behavioral differences between high and low procrastinators. Journal of
Counseling Psychology, 33(4), 387-394.

DOI: http://dx.doi.org/10.1037/0022-

0167.33.4.387

- Schneider Rosen, K., \& Burke, P. B. (1999). Multiple attachment relationships within families: Mothers and fathers with two young children. Developmental Psychology, 35(2), 436-444. DOI: 10.1037/0012-1649.35.2.436.

- Skelton, C. (2003). Male Primary Teachers and Perceptions of Masculinity.

Educational Review, 55(2), 195-209.

DOI:

https://doi.org/10.1080/001319103200007 2227

- $\quad$ Steele, H., Steele, M., \& Fonagy, P. (1996). Associations among attachment classifications of mothers, fathers, and their infants. Child Development, 67(2), 541-555. DOI:

http://dx.doi.org/10.2307/1131831

- $\quad$ van IJzendoorn, M.H., Goldberg, S., Kroonenberg, P.M., \& Frenkel, O.J. (1992). The relative effects of maternal and child problems on the quality of attachment: A meta-analysis of attachment in clinical samples. Child Development, $63,840-858$.

- Wentzel, K. R. (1999). Socialmotivational processes and interpersonal relationships: Implications for understanding motivation at school. Journal of Educational Psychology, 91(1), 76-97. DOI: http://dx.doi.org/10.1037/00220663.91.1.76 